\title{
Impact of Soil Amendments on Soil Heat and Moisture Content in Calcareous soil \\ Hoda A.Elia ${ }^{1}$
}

\begin{abstract}
A field experiment was carried out to study the impact of soil amendments on soil heat content and soil moisture content in calcareous soil. Experimental field, located in the Desert Research Center's station in_Ras Sudr, South Sinai. Three rates of sheep dung were used $(0,5$ and 10 ton/ fed), sheep wool (0.5 and 1 ton/fed) and their combination (5 ton/fed sheep dung and each of 1 and 0.5 ton/fed sheep wool). Two rates $100 \%$ and $75 \%$ of available water were applied using drip irrigation system. Sorghum (Sorghum bicolor L. Monech) was planted in $1^{\text {st }}$ June, 2016. The soil temperature was recorded and moisture content was determined at the same times after each plants cutting every an hour, from 9.00 am until $6.00 \mathrm{pm}$ in July, August and September months for 0 - 5, 5- 10 and $10-15$ cm soil depths. Heat content was calculated in Calories for each soil depth.
\end{abstract}

The obtained results reveal that, the maximum soil heat content increased in the following order : 10 ton/fed sheep dung > 5 ton/fed sheep dung > combination $(5$ ton/fed sheep dung with 1 ton /fed sheep wool > combination (5 ton / fed sheep dung +0.5 ton /fed sheep wool) $>1$ ton /fed sheep wool $>0.5$ ton $/$ fed sheep wool $>$ control (un treated).

The following equation: $(A)=\int_{1}^{9}(x) d x$ was applied to calculate the total area under curve of the heat content ( Heat Index HI), In July month, the $0-5 \mathrm{~cm}$ soil depth, results showed increase for Heat Index, of 10 ton /fed and 5 ton/fed sheep dung amendments with (100 and $75 \%$ water applied) compare to control. The rates of increasing were $13.32,10.49 \%, 13.78$ and $12.03 \%$ for up above treatments respectively. While, the increase rate of the integrated heat content of 1 ton /fed and 0.5 Ton/ fed sheep wool with (100 and $75 \%$ water applied) was $<1 \%$. In the soil depth $5-10 \mathrm{~cm}$, the results showed the rates of increasing were $14.63,12.18,10.07$ and $11.68 \%$ for sheep dung amendments, 1.18 and $1.55 \%$ of 1 ton /fed and 0.5 ton/ fed sheep wool, respectively. The increase of (Heat Index, HT) was slightly in $10-15 \mathrm{~cm}$ soil depth. The same trend was found in August and September months. But HI in August month was higher than the total heat content under area in July and September.

The results were highly significant in $\mathrm{HI}$ as $100 \& 75 \%$ of irrigation water applied for 0-5 and $5-10 \mathrm{~cm}$ soil depths. There was no significant of sheep wool treatment. There was no significant for $10-15 \mathrm{~cm}$ soil depth each of soil amendments and water applied in July and August month, but it had significant differences in September month. The results showed a significant increment in $\mathrm{HI}$ in the depth $10-15 \mathrm{~cm}$ at the end of the experiment, due to the influence of root growth.

Keywords: heat capacity, soil heat content, soil temperature, soil amendments and soil moisture retention.

\section{INTRODUCTION}

Soil temperature is one of the important factors that influence soil properties processes involved in plant growth. It governs the soil physical, chemical and biological processes (Buchan, 2001). It also influences the interspheric processes of gas exchange between the atmosphere and the soil (Lehnert et al., 2014), (Tyson et al., 2001). The amount of radiation received by the soil affects soil temperature (Haskel et al., 2010), the heat capacity of a soil depends on factors which are inherent to the soil itself (include the mineralogical composition and the organic component of the soil) and those which can be managed or controlled to a certain extent (Wierenga et al., 1969). Factors influencing soil heat capacity that can be managed externally include water content and soil density (Yadav \& Saxena, 1973). Water content plays a major role in soil heat capacity but is the most difficult to manage. Soil management affects heat capacity because practices that cause soil compaction will increase the bulk density and decrease the porosity of a soil.

Also, the thermal properties in the soil depend on soil state and its physical properties, and may be considered as semi-stable Lehnert et al (2014). However, information on thermal properties of soils is very limited. Thermal properties of the soil affected by its mineralogical composition, particle size distribution, organic matter content, density of the solid phase and the bulk density of the soil, water content and temperature. Bachmann et al (2001). These properties are temporarily stable or semi-stable, except for soil water content and temperature, which are spatially and temporarily variable Usowicz (1992). Soil organic matter amendment can be increase soil temperatures during solarization, so it improves the efficiency of solarization; it has been reported that soil temperature is 2-3 ${ }^{\circ} \mathrm{C}$ higher during solarization with compost than without compost (Gamliel and Stapleton, 1993) due to exothermic microbial activity stimulated by organic 
matter application (Simmons et al., 2013). While addition of organic matter improves soil heating, organic matter decomposition during the solarization process is poorly understood. Destabilizing soil with organic matter can increase soil temperature during solarization as a result of increased soil biological activity Komariah et al., (2011). Christopher et al (2016), Demonstrated the role organic matter management plays on temperature elevation and organic acid accumulation, the combined disinfection power of organic acids and enhanced heating suggest that biosolarization could significantly cut solarization time from weeks to days. Abu-Hamdeh, Nidal. (2014). found that, specific heat increased with increased moisture content of sand and loam soils. Also, volumetric heat capacity increased with increased moisture content and soil density. The differences between the observed and predicted results were very small. Loam soil generally had higher specific heat and volumetric heat capacity than sandy soil for the same moisture content and soil density.

Soil moisture content: has definite influence soil heat distribution down the profile. The flow of heat is higher in a wet soil than in a dry soil where the pores filled with air. The rate of heat dissipation increases with moisture content Ochsner et al. (2001).

Soil temperature is a vital factor for plant growth, microbial activity, chemical, physical reactions in soil, water, and air movement in soil and consequently nutrient availability to plants. Heat transfer in soil is of great importance for both practical and academic reasons, the rate of heat transfer affects the rate of soil warming up and cooling down. The purpose of this study is to evaluate the changes in soil temperature as affected by some soil conditioners.

Temperature is a measure of the heat intensity in the body or the level of heat and measured as $\left({ }^{\circ} \mathrm{C},{ }^{\circ} \mathrm{F},{ }^{\circ} \mathrm{K}\right)$ Celsius, Fahrenheit or Calvin, while heat content is the amount of heat existing in a body based on its thermal capacity or heat capacity. It can defined as the amount of temperature change in the soil in response to the absorption or release of heat. The heat capacity in calories per gram called specific heat, unit (calorie $\left./ \mathrm{cm}^{3}\right) . \quad \mathrm{Cv}=\Sigma\left(\rho \mathrm{d} \mathrm{cs}+\rho \mathrm{d}_{\mathrm{w}} \mathrm{cw}\right) \quad$ where: $\mathrm{Cv}$ is the volumetric heat capacity of moist soil, $\mathrm{Cal} / \mathrm{cm}^{3} /{ }^{\circ} \mathrm{C}$; and $\rho \mathrm{d} c \mathrm{cs}$ is the volumetric heat capacity of dry soil, Cal $/ \mathrm{cm}^{3} /{ }^{\circ} \mathrm{C}$. $\rho \mathrm{d}_{\mathrm{w}} \mathrm{cw}$ is the volumetric heat capacity of water, $\mathrm{Cal} / \mathrm{mm}$ of water $/{ }^{\circ} \mathrm{C}$.

\section{MATERIALS AND METHODS}

The current work was carried out in the Agricultural Field Experiment Station of the Desert Research Center (DRC) in Ras Sudr, South Sinai, to study the impact of soil amendments on soil heat and moisture content in calcareous soil. During the growth summer season 2016, using three rates of sheep dung (10, 5 and 0 ton/ fed), sheep wool ( 1 and 0.5 ton/fed) according to Andrej Voncina and Rok Mihelic (2013) and their combinations (5 ton/fed sheep dung + each of 1.0 and 0.5 ton/fed sheep wool). Soil amendments were mixed with the upper $15 \mathrm{~cm}$ soil depth, and two rates of irrigation water were applied using drip irrigation system at $100 \%$ and $75 \%$ of available water. Ec and $\mathrm{pH}$ of the irrigation water were, $8.96 \mathrm{dS} / \mathrm{m}$ and 7.63 respectively. Each plot was $2 \times 3 \mathrm{~m}$. Sorghum, (bicolor L. Monech) was planted in the $1^{\text {st }}$ June 2016. Cutting the plants was done in three stages; the first cutting was 40 days after planting (DAP), the $2^{\text {nd }}$ and the $3^{\text {rd }}$ cuttings were after 70 and 100 days from the first cutting.

After cutting, when plants $10 \mathrm{~cm}$ length, soil moisture samples were taken to determined soil moisture content. soil temperature was determined and recorded at the same time every hour from 9.00 am until $6.00 \mathrm{pm}$ through July, August and September for 0 -5, 5- 10 and $10-15 \mathrm{~cm}$ soil depths. Digital thermometer with the accuracy of $0.1^{\circ} \mathrm{C}$ was used to record soil temperature (Taylor and Jackson, 1965). To calculate soil heat content, air temperature was measured at 1 meter height above soil surface by using thermometer. Heat content was calculated as Calories for each soil layer and the total heat retained was calculated by the formula $\mathrm{H}=\mathrm{ms}$ $\mathrm{cs}+\mathrm{mw} \mathrm{cw}$.

where: $\mathrm{H}$ is heat content of the soil in calories, cs and $\mathrm{cw}$, are the specific heats in calorie/gram $/{ }^{\circ} \mathrm{C}$ of dry soil particles and soil water, respectively. $\mathrm{ms}=$ mass of dry soil profiles, $\mathrm{mw}=$ mass of water

$\mathrm{H}_{\mathrm{T}}=\mathrm{Hs}$ (amount of heat retained by solid particles) $+\mathrm{Hw}$ (amount of water heat). Where, Hs is the product of the mass of the oven- dry soil particles and heat capacity the soil and $\mathrm{Hw}$ was estimated by multiplying the volumetric water content $\left(\theta_{\mathrm{V}}\right)$ of each soil layer and the heat capacity of water. Afterwards, the total amounts of heat retained in each layer of treatments obtained via multiplying $\left(\mathrm{H}_{\mathrm{T}}\right)$ by the recorded soil temperature at the considered time. The relationship between heat content and the time of each treatment was determined. An example of 10 ton/fed sheep dung, under $100 \%$ irrigation water applied in $0-5 \mathrm{~cm}$ soil depth.

The area of total heat content under curve (Heat Index), was calculated following equation:

$$
\text { Heat Index }(A)=\int_{1}^{9}(x) d x \text {. }
$$

Soil sample from 0-30 cm soil layer collected for the determination of soil physical properties according to Klute (1986). At the end of the growing season the sorghum (ton /fed) productivity, fresh weight productivity recorded as the three cuttings. The analysis 
Table 1a. Analytical data of the initial soil $(0-30 \mathrm{~cm})$ of Wadi Sudr under study

\begin{tabular}{|c|c|c|c|c|c|c|c|c|c|c|c|c|c|c|}
\hline \multicolumn{4}{|c|}{ Particlesize distribution \% } & \multirow[b]{2}{*}{ 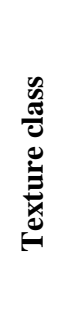 } & \multirow[b]{2}{*}{$\begin{array}{l}\stackrel{\tilde{B}}{\Xi} \\
\sum_{0}^{\infty 00} \\
\dot{0}\end{array}$} & \multirow[b]{2}{*}{$e^{\infty}$} & \multirow[b]{2}{*}{ 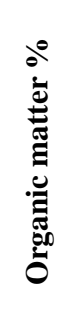 } & \multirow[b]{2}{*}{ 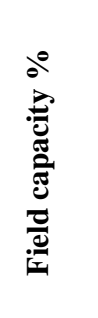 } & \multirow[b]{2}{*}{ 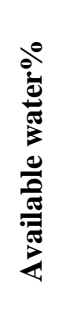 } & \multirow[b]{2}{*}{ 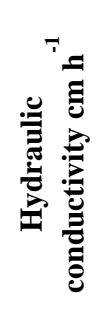 } & \multirow{2}{*}{ 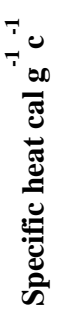 } & \multirow[b]{2}{*}{ 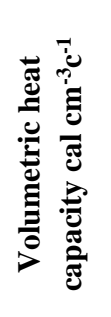 } & \multirow[b]{2}{*}{ 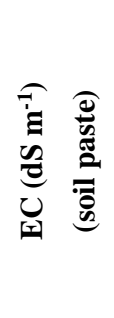 } & \multirow[b]{2}{*}{ 空 } \\
\hline $\begin{array}{c}\text { Coarse } \\
\text { S. }\end{array}$ & $\begin{array}{c}\text { Fine } \\
\text { S. }\end{array}$ & Silt & Clay & & & & & & & & & & & \\
\hline 13.74 & 64.86 & 12.45 & 8.95 & L.S. & 1.51 & 51.84 & 0.42 & 13.63 & 9.45 & 7.32 & 0.24 & 0.3624 & 9.16 & 7.89 \\
\hline
\end{tabular}

Table 1b. Chemical Analysis of soil amendments applied.

\begin{tabular}{|c|c|c|c|c|c|c|c|c|c|c|c|c|}
\hline $\begin{array}{l}\text { Amendment } \\
\text { type }\end{array}$ & 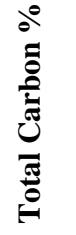 & $\begin{array}{l}\text { ठ0 } \\
\mathbf{Z} \\
\frac{\pi}{0} \\
0\end{array}$ & 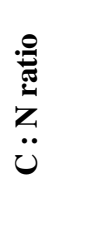 & $\frac{\Delta}{0}$ & 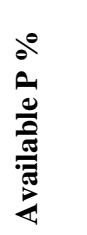 & 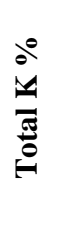 & $\begin{array}{l}0 \\
0 \\
\overline{0} \\
\vec{x} \\
0 \\
0\end{array}$ & 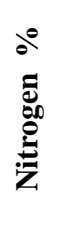 & 吕 & 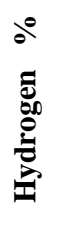 & 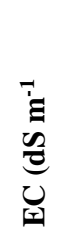 & 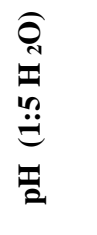 \\
\hline Sheep dung & 8.97 & 0.59 & 15.21 & 0.49 & 0.018 & 0.58 & ---- & ---- & ---- & ---- & 5.09 & 7.75 \\
\hline Sheep wool & 50.5 & 16.5 & 3.06 & 0.61 & 0.022 & 0.67 & 22.0 & 16.5 & 3.7 & 6.8 & ---- & 7.3 \\
\hline
\end{tabular}

of variance of two Way Completely Randomized design (ANOVA and L.S.D. 0.05) of heat content under soil amendments and rates of irrigation of water applied. The physical and chemical properties of soil and properties of amendments and analysis of water quality are showed in tables (1a and $1 \mathrm{~b}$ ).

\section{RESULTS AND DISCUSSION}

\section{Effect of amendments treatment on soil heat content under $100 \%$ water applied:}

Soil heat content and moisture content of the studied soils as affected by various types of soil amendments and their application levels are given in Tables (2-4). It is evident that treating soil with sheep dung, sheep wool and their combination had a great difference on the heat content of soil. However, the tendency of the variation in the heat content was appreciable.

In the soil depths $0-5,5-10$ and $10-15 \mathrm{~cm}$, the data in Table (2) and Figs (1-6), showed that the total heat content values were higher in the upper soil depth $0-5$ and $5-10 \mathrm{~cm}$. Then a sharply decrease in soil heat content with the increasing soil depth under various types rates of soil amendments, irrigation water applied. Also, the total heat content of control and sheep wool treatment of all the rates was lowest compared to sheep dung treatments.

Data in Table (2) and Figs (1, 2\& 3), showed the total heat content in July month under various types of soil amendments and their application levels (100 water applied) in $0-5,5-10$ and $10-15 \mathrm{~cm}$ soil depths, were increased in the upper soil layers $0-5$ and $5-10 \mathrm{~cm}$ depths. In addition, it increased with time from 9.0012.00AM to reach a maximum at $12.00-3.00 \mathrm{PM}$ in $0-5$ and $5-10 \mathrm{~cm}$. Then, it was decreased gradually until to reach $6.00 \mathrm{PM}$. In addition, the values of total heat content of control and sheep wool treatment of all rates was lowest compared to sheep dung treatments.

The total heat content under 10 ton /fed sheep dung treatment was higher than that of the other treatments, this result agreed with (Gamliel and Stapleton, 1993). This finding may attributed to the presence of highly moisture content in the soil layer treated with sheep dung. The results declared that the values of total heat content for sheep wool treatments was lower than the values of total heat content under 5 ton/fed sheep dung with the times of experiment. In the same time, it was noticed that the values of the total heat content in the upper layers $0-5$ and $5-10 \mathrm{~cm}$ of control soil was lower than the heat content values of each of all sheep dung and sheep wool treatments. Also, the results showed that the minimum soil heat content of the soil at any given depths were the lowest in control soil treatments and increased in soil treatments sheep dung.

\section{Effect of amendments treatment on soil heat content under $75 \%$ water applied:}

Data in Tables (2) and Figs (4, 5 and 6), reveal that there is considerable variation of heat content along with water content. 
Table 2. The effect of soil amendments on soil heat content under two rates of irrigation water applied through during the monthly July.

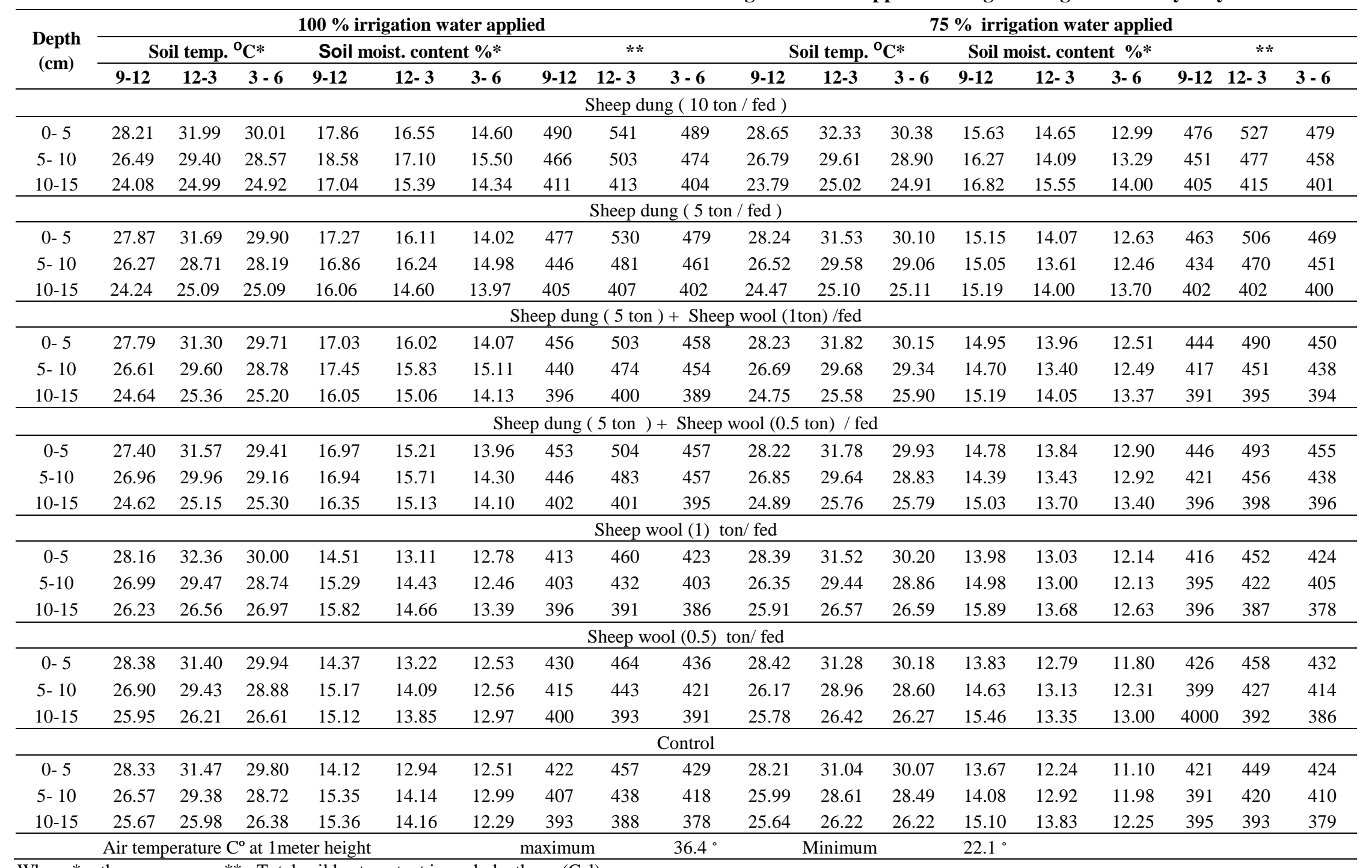

Where $^{*}=$ the average $\quad * *=$ Total soil heat content in each depth $\mathrm{cm}(\mathrm{Cal})$. 


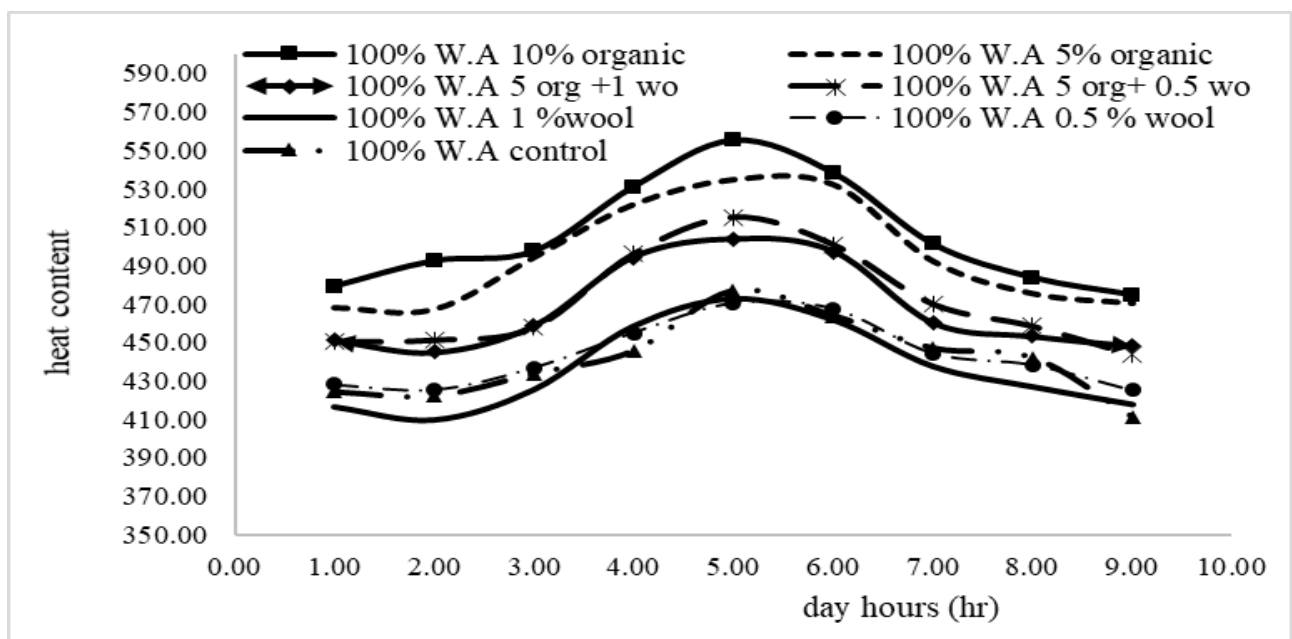

Fig. 1. Influence of soil amendments on heat content in soil at $(0-5 \mathrm{~cm})$ depth in July month.

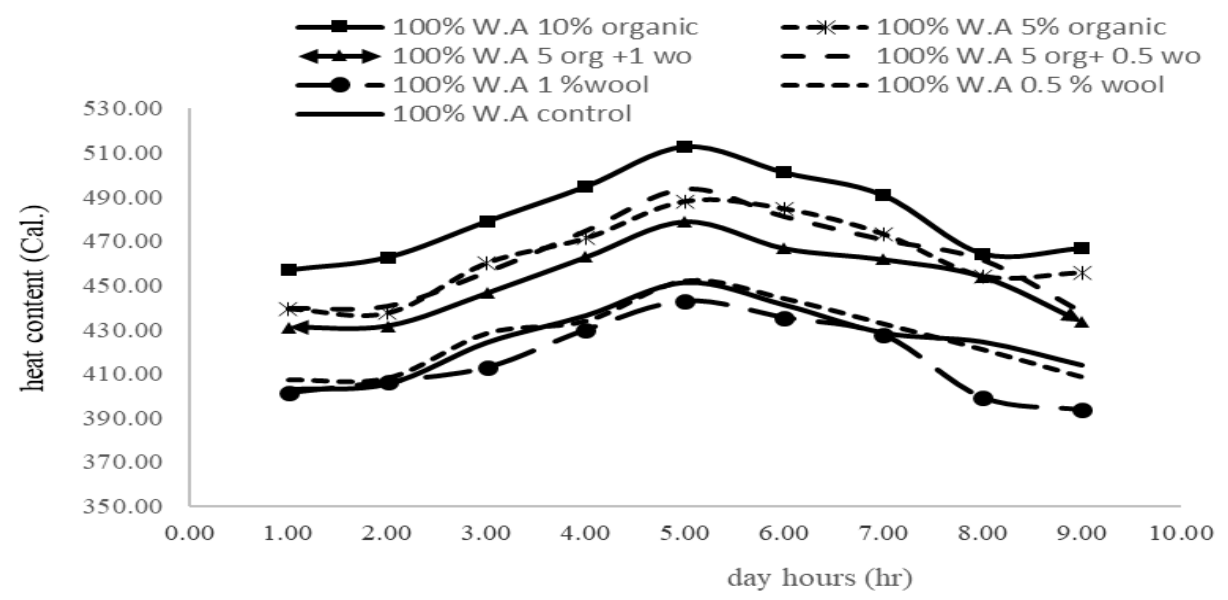

Fig. 2. Influence of soil amendments on heat content in soil at $(5-10 \mathrm{~cm})$ depth in July month.

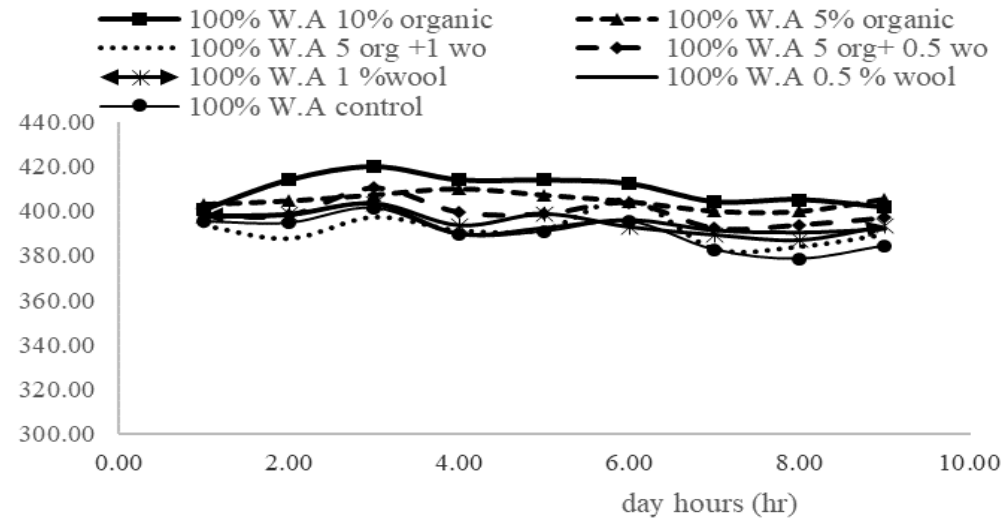

Fig. 3. Influence of soil amendments on heat content in soil at $(\mathbf{1 0 - 1 5} \mathrm{cm})$ depth in July month. 


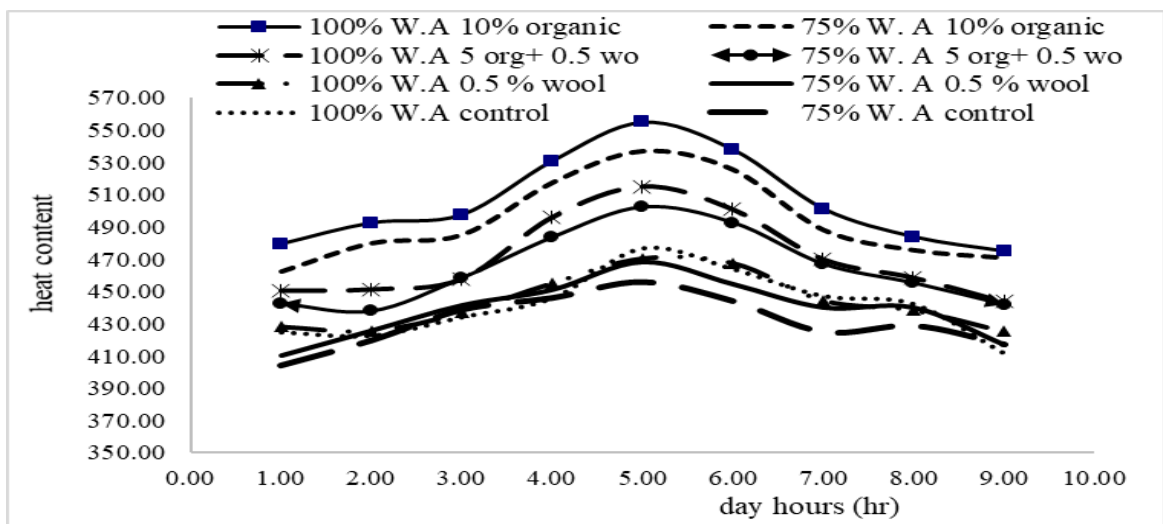

Fig. 4. Influence of soil water applied on heat content in soil at $(0-5 \mathrm{~cm})$ depth in July month.

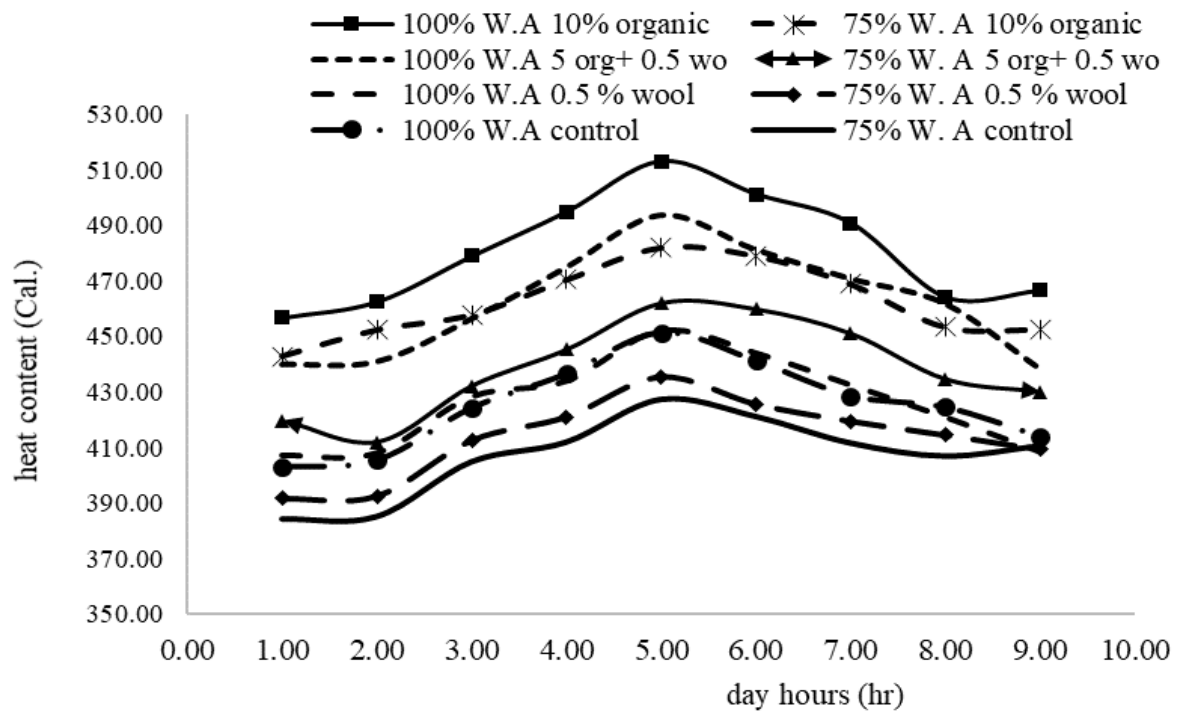

Fig. 5. Influence of soil water applied on heat content in soil at $(0-5 \mathrm{~cm})$ depth in July month.

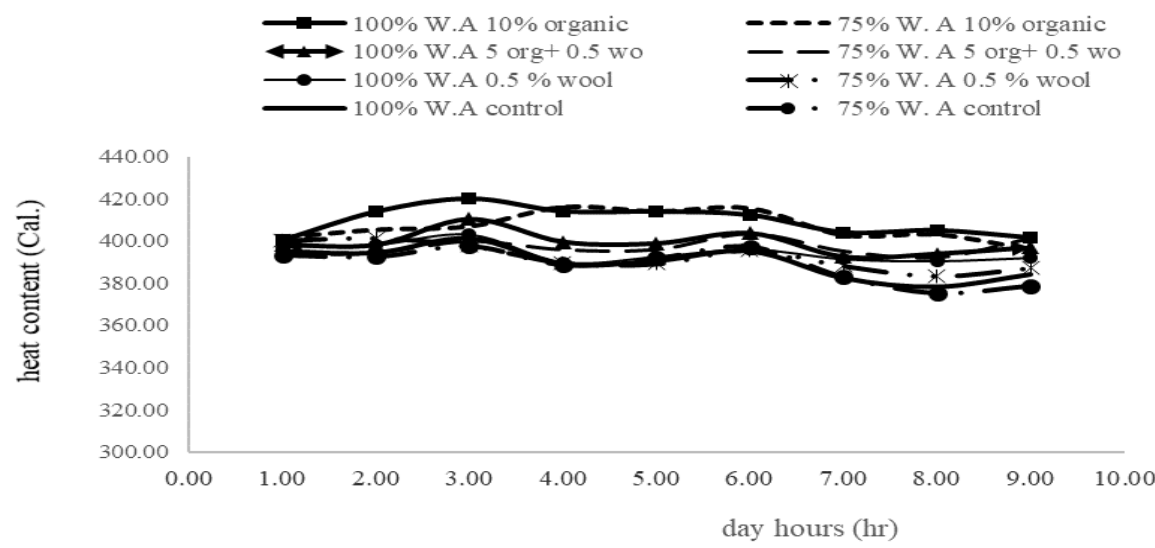

Fig. 6. Influence of soil water applied on heat content in soil at (10-15 cm) depth in July month. 
Also, there was increase in heat content with increasing rate of water applied in soil, which results in the formation of a pronounced peak and a highly in the heat content curve of $100 \%$ available water (water applied) but, it was low in $75 \%$ available water (water applied) under the same rate of soil amendments.

This may be the amount of heat needed to increase the temperature of soil is strongly related to water content. It takes only 0.2 calories of heat energy to increase the temperature of I gram of dry soil $1{ }^{\circ} \mathrm{C}$; compared with 1.0 calories per gram per degree for water (Kohnke 1982). The increase of moisture content decreases the soil temperature also resulting in higher storage capacity at higher moisture content, agreed with (Al-Kayssi et al 1991).

The obvious effect of adding 10 ton/ fed sheep dung on increasing the total heat content in soil of the upper layer $0-5$ and $5-10 \mathrm{~cm}$ could be attributed to its black colour of sheep dung and keep the higher water holding capacity. This is because the high absorptivity of dark colours to incidence of solar radiation than the light ones (wool sheep treatments and control samples). These results show that, heat content increase, also the lower soil moisture content with increased the temperature of its top layer as a result of decreasing its heat energy under $75 \%$ water applied. Also, The lower total heat content of the upper layers treated with sheep wool and soil control (non treated) relative to the sheep dung could be explained on basis of the sheep wool as insulator to heat, due to its low heat capacity and lower of its retention moisture content. The higher moisture content lowers soil temperature due to the higher of below heat vaporization of water molecules $\approx 585 \mathrm{cal}$ /gm. Therefore, the temperature of the lower layer was always less than the upper one. The difference in temperature between the treated soil and the control was small at $10-15 \mathrm{~cm}$ soil depth. The difference in temperature between the first depth $(0-5 \mathrm{~cm})$ and the second one $5-10 \mathrm{~cm}$, was small in the case of $5 \mathrm{ton} / \mathrm{fed}$ sheep dung, (5ton/fed sheep dung +1 ton/fed sheep wool) and (5 ton/fed sheep dung +0.5 ton/fed sheep wool) relative to treated soil with 10 ton /fed sheep dung.

Data in tables ( $3 \& 4)$ reveal that the same trend, in August and September months but the total soil heat content was higher in August than the total heat content in July and September, this due to increased soil temperatures through August month.

Concerning to the effect of amendments on soil heat content, the data reveals that the maximum soil heat content increased in the following order to: 10 ton/fed sheep dung > 5 ton/fed sheep dung > combination 5 ton/fed sheep dung with 1 ton /fed sheep wool > combination 5 ton/fed sheep dung with 0.5 ton /fed sheep wool $>1$ ton /fed sheep wool $>0.5$ ton /fed sheep wool > control (non treatment). This may be due to that the sheep dung was as a physical barrier between the soil and atmospheric air, consequently improved soil moisture retention and heat balance of the soil layers , (Al-Kayssi, 2009).

Data in Figs (1-6) reveal that, In general, there was a variation in heat content through the measurement in daytime periods which results in the formation of a pronounced peak and a highly in the temperature curve of the surface layers but, it was low in the deeper layers of all treatments. It may attribute such a formation to the following reasons, usually, soil treatment and water content in the soil, the heat capacity of the soil increases, thereby requiring more heat per degree rise in temperature. In addition the sunshine hours during this period. Also, there is considerable strong relationship between heat content and water content of the soil. The data show that the increase in heat content with increasing rate of water applied in soil, which results in the formation of a pronounced peak and a highly in Heat Index of $100 \%$ water applied but, it was low of $75 \%$ water applied.

\section{Integral Method:}

In order to follow the cumulative heat content (in Calories) over the measure time of both soil temperature and moisture, the area under curve Figs (1-6), cumulative heat content can be found from the measurements calculated of Heat Index in each soil amendments treatment under the rates of water applied during a given interval of time from the relation : $(A)=\int_{1}^{2}(x) d x$ Where $\mathrm{A}=$ The cumulative heat content (Heat Index) calculated at period of time (1-9) . An example of 10 ton/fed sheep dung, under $100 \%$ irrigation water applied in 0-5 cm soil depth.

Polynomial equation,

$\mathrm{y}=-0.0781 \mathrm{x}^{6}+2.395 \mathrm{x}^{5}-28.252 \mathrm{x}^{4}+160.54 \mathrm{x}^{3}-453.24 \mathrm{x}^{2}$

$+603.68 \mathrm{x}+194.18$

$\mathrm{R}^{2}=0.999$ where $\mathrm{y}=$ Heat Index through diurnal $(9.00$ $\mathrm{AM}: 6.00 \mathrm{PM})$, $\mathrm{x}$ time.

In addition calculated the total area under curve (Heat Index) by integrated. Integral as the following equation: $(A)=\int_{1}^{9}(x) d x$ where, Heat Index $(\mathrm{A})=$ 4883.68 Calories.

Data in table (5) show the influence of soil amendments and water applied on the Heat Index (cumulative heat content) of 0-5, 5-10 and 10-15 cm soil depth. 
Table 3. The effect of soil amendments on soil heat content under two rates of irrigation water applied through during the monthly August.

\begin{tabular}{|c|c|c|c|c|c|c|c|c|c|c|c|c|c|c|c|c|c|c|}
\hline \multirow{3}{*}{$\begin{array}{c}\text { Depth } \\
(\mathrm{cm})\end{array}$} & \multicolumn{9}{|c|}{$100 \%$ irrigation water applied } & \multicolumn{9}{|c|}{$75 \%$ irrigation water applied } \\
\hline & \multicolumn{3}{|c|}{ Soil temp. ${ }^{\circ} \mathrm{C}^{*}$} & \multicolumn{3}{|c|}{ Soil moist. content \%* } & \multicolumn{3}{|c|}{$* *$} & \multicolumn{3}{|c|}{ Soil temp. ${ }^{\circ} \mathrm{C}^{*}$} & \multicolumn{3}{|c|}{ Soil moist. content \%* } & \multicolumn{3}{|c|}{$* *$} \\
\hline & $9-12$ & 12-3 & $3-6$ & $9-12$ & 12- 3 & 3- 6 & $9-12$ & 12- 3 & $3-6$ & $9-12$ & $12-3$ & $3-6$ & $9-12$ & 12- 3 & 3- 6 & $9-12$ & 12- 3 & $3-6$ \\
\hline \multicolumn{19}{|c|}{ Sheep dung ( 10 tons / fed ) } \\
\hline $0-5$ & 29.81 & 33.87 & 31.82 & 17.06 & 16.50 & 14.20 & 509 & 573 & 514 & 30.34 & 34.61 & 32.24 & 15.40 & 14.00 & 12.28 & 502 & 557 & 500 \\
\hline $5-10$ & 28.94 & 32.44 & 30.49 & 17.07 & 16.07 & 14.40 & 495 & 544 & 495 & 28.83 & 32.61 & 30.20 & 15.59 & 14.61 & 12.93 & 479 & 531 & 475 \\
\hline $10-15$ & 25.12 & 26.29 & 26.31 & 16.37 & 15.00 & 15.04 & 424 & 432 & 432 & 24.13 & 25.24 & 25.11 & 15.63 & 14.07 & 13.13 & 401 & 407 & 397 \\
\hline \multicolumn{19}{|c|}{ Sheep dung ( 5 tons / fed ) } \\
\hline $0-5$ & 30.42 & 33.61 & 31.97 & 15.76 & 14.46 & 14.19 & 505 & 544 & 514 & 30.51 & 33.73 & 32.11 & 14.55 & 13.07 & 11.04 & 494 & 530 & 483 \\
\hline $5-10$ & 28.46 & 32.05 & 29.00 & 16.54 & 15.03 & 14.38 & 480 & 525 & 469 & 27.78 & 30.82 & 29.38 & 15.42 & 14.28 & 12.30 & 458 & 497 & 455 \\
\hline $10-15$ & 25.04 & 26.06 & 25.49 & 15.00 & 14.30 & 14.09 & 410 & 420 & 409 & 25.00 & 26.10 & 25.71 & 15.00 & 13.68 & 13.23 & 409 & 415 & 406 \\
\hline \multicolumn{19}{|c|}{ Sheep dung ( 5 ton ) + Sheep wool (1 ton) /fed } \\
\hline $0-5$ & 30.66 & 33.80 & 32.15 & 15.81 & 14.46 & 14.24 & 486 & 521 & 493 & 30.70 & 34.05 & 32.02 & 14.46 & 13.05 & 11.80 & 473 & 509 & 465 \\
\hline $5-10$ & 28.67 & 31.77 & 29.07 & 16.82 & 15.20 & 14.57 & 464 & 497 & 449 & 28.29 & 31.51 & 29.68 & 15.19 & 13.94 & 12.06 & 443 & 480 & 434 \\
\hline $10-15$ & 25.73 & 26.02 & 25.79 & 15.80 & 14.83 & 15.11 & 408 & 404 & 403 & 25.32 & 26.27 & 26.04 & 15.20 & 14.02 & 13.74 & 396 & 401 & 395 \\
\hline \multicolumn{19}{|c|}{ Sheep dung $(5$ ton $)+$ Sheep wool $(0.5$ ton $) /$ fed } \\
\hline $0-5$ & 30.90 & 34.00 & 32.32 & 15.73 & 14.46 & 14.28 & 498 & 534 & 506 & 30.57 & 34.36 & 32.02 & 14.38 & 13.04 & 12.57 & 480 & 524 & 483 \\
\hline $5-10$ & 28.88 & 31.61 & 29.14 & 16.94 & 14.55 & 14.76 & 477 & 498 & 461 & 28.66 & 32.11 & 29.98 & 14.91 & 13.17 & 12.02 & 455 & 491 & 447 \\
\hline $10-15$ & 25.13 & 25.98 & 26.08 & 16.25 & 15.36 & 14.82 & 410 & 416 & 413 & 25.48 & 26.09 & 25.69 & 14.43 & 14.34 & 14.26 & 400 & 409 & 402 \\
\hline \multicolumn{19}{|c|}{ Sheep wool (1) ton/ fed } \\
\hline $0-5$ & 29.91 & 33.74 & 32.03 & 15.38 & 14.04 & 12.57 & 447 & 490 & 450 & 30.48 & 34.24 & 32.64 & 14.07 & 12.11 & 11.31 & 447 & 481 & 449 \\
\hline $5-10$ & 28.15 & 32.13 & 30.23 & 16.06 & 13.17 & 12.31 & 427 & 458 & 422 & 29.12 & 32.19 & 30.43 & 14.06 & 12.69 & 11.27 & 427 & 458 & 419 \\
\hline $10-15$ & 26.52 & 28.38 & 26.93 & 16.49 & 13.86 & 13.71 & 407 & 411 & 388 & 26.36 & 26.89 & 26.52 & 16.21 & 15.31 & 15.10 & 405 & 406 & 398 \\
\hline \multicolumn{19}{|c|}{ Sheep wool (0.5) ton/ fed } \\
\hline $0-5$ & 30.06 & 33.40 & 32.27 & 15.15 & 13.50 & 11.81 & 463 & 497 & 462 & 30.58 & 33.65 & 31.95 & 13.40 & 11.42 & 10.87 & 454 & 478 & 448 \\
\hline $5-10$ & 27.72 & 31.35 & 29.93 & 16.04 & 13.74 & 12.50 & 435 & 469 & 436 & 28.50 & 31.79 & 30.20 & 13.77 & 11.96 & 11.07 & 426 & 457 & 425 \\
\hline $10-15$ & 26.00 & 27.27 & 26.87 & 15.98 & 14.13 & 13.79 & 408 & 411 & 402 & 26.02 & 27.44 & 26.48 & 15.99 & 14.90 & 14.58 & 408 & 421 & 403 \\
\hline \multicolumn{19}{|c|}{ Control } \\
\hline $0-5$ & 29.89 & 33.52 & 32.50 & 14.87 & 12.96 & 11.11 & 453 & 487 & 453 & 30.48 & 33.07 & 31.27 & 12.79 & 10.72 & 10.70 & 446 & 462 & 437 \\
\hline $5-10$ & 27.30 & 30.52 & 29.63 & 16.02 & 14.11 & 12.35 & 424 & 455 & 425 & 28.10 & 31.47 & 29.96 & 13.70 & 11.50 & 10.39 & 419 & 447 & 415 \\
\hline $10-15$ & 25.80 & 26.80 & 26.81 & 15.77 & 14.40 & 13.87 & 399 & 402 & 398 & 25.67 & 26.75 & 26.43 & 15.77 & 14.48 & 14.38 & 401 & 406 & 401 \\
\hline \multicolumn{9}{|c|}{ Air temperature $\mathrm{C}^{\circ}$ at 1 meter height } & $39.5^{\circ}$ & \multicolumn{3}{|c|}{ Minimum } & $24.2^{\circ}$ & & & & & \\
\hline
\end{tabular}

Where $^{*}=$ the average $\quad * *=$ Total soil heat content in each depth $\mathrm{cm}(\mathrm{Cal})$ 
Table 4. The effect of soil amen dments on soil heat content under two rates of irrigation water applied through during the monthly September.

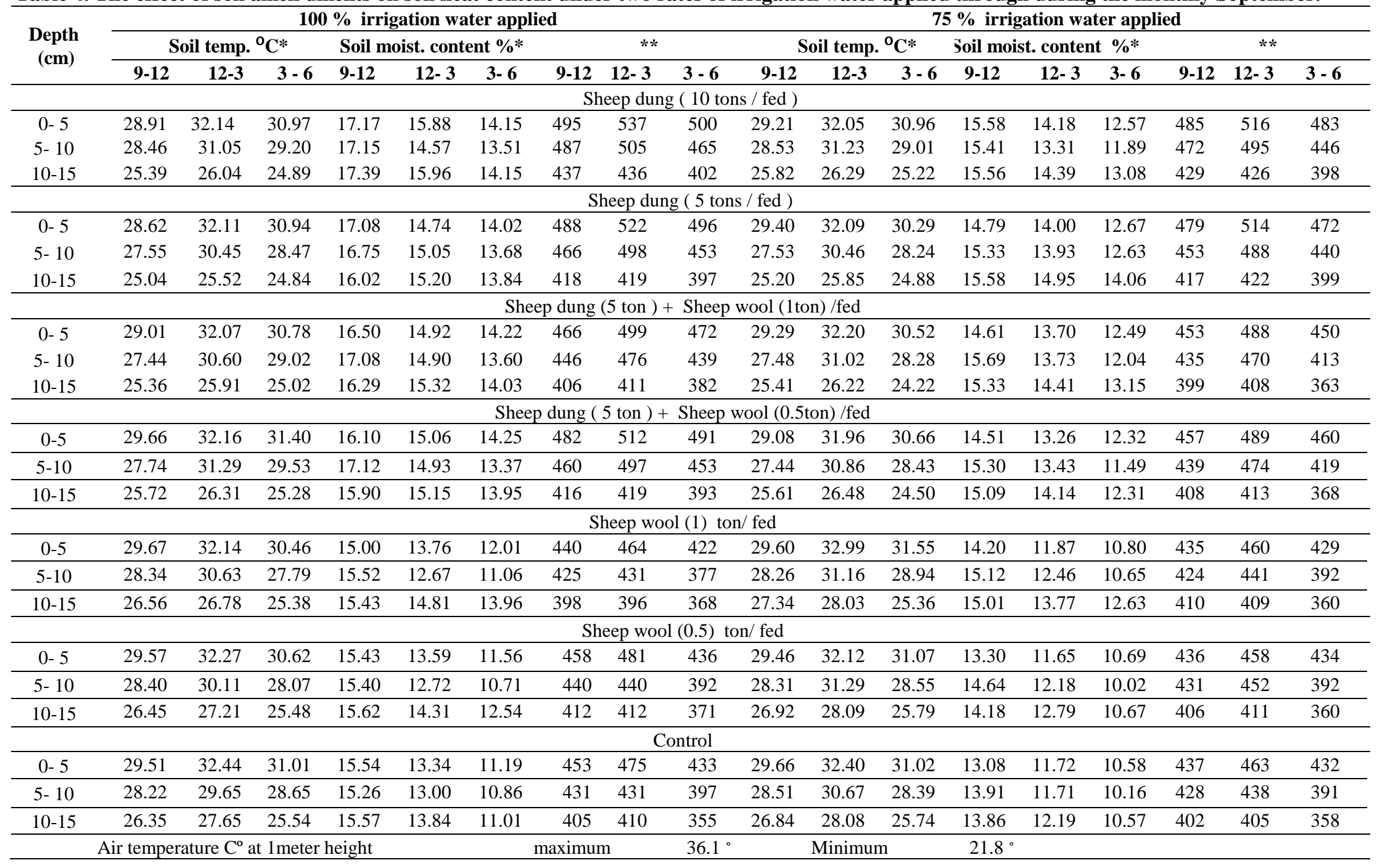


Table 5. Heat Index (Total area of cumulative) calculated under curves by integration

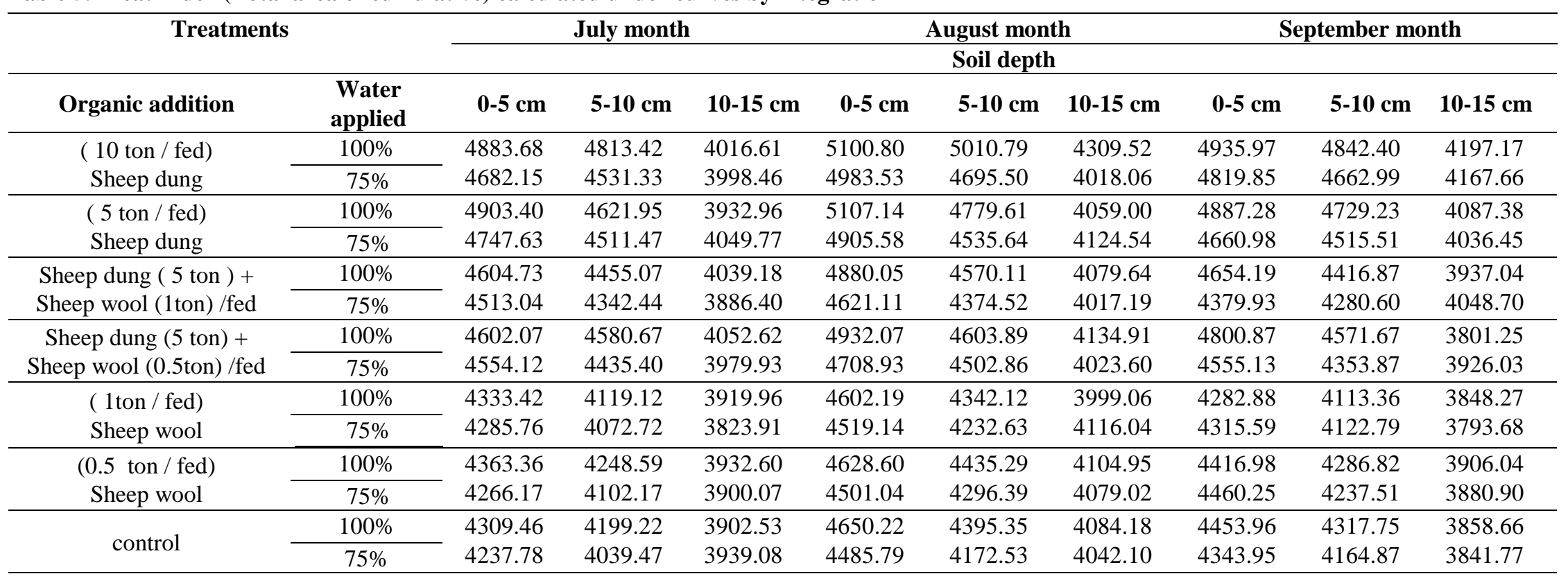


Table 6. Effect of different treatments on some soil physical parameters.

\begin{tabular}{|c|c|c|c|c|c|c|c|}
\hline \multirow[b]{2}{*}{ Treatments } & \multirow{2}{*}{ 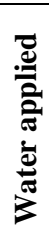 } & \multicolumn{2}{|c|}{ Soil moisture content at } & \multirow{2}{*}{ 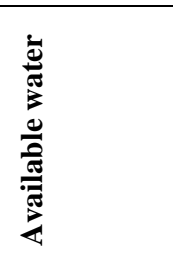 } & \multirow{2}{*}{ 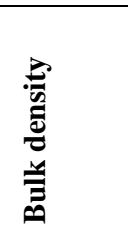 } & \multirow{2}{*}{ 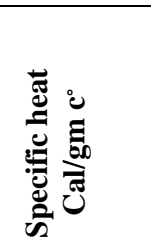 } & \multirow{2}{*}{ 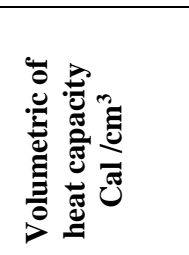 } \\
\hline & & 0.1 bar & 15 bar & & & & \\
\hline Sheep dung ( 10 ton / fed) & & 21.34 & 7.07 & 14.27 & 1.4 & 0.31 & 0.4340 \\
\hline Sheep dung ( 5 ton / fed & & 19.28 & 7.41 & 11.87 & 1.42 & 0.30 & 0.4260 \\
\hline Sheep dung ( 5 ton $/$ fed $)+1$ ton/fed sheep wool & bo & 18.74 & 7.51 & 11.23 & 1.37 & 0.30 & 0.4110 \\
\hline Sheep dung ( 5 ton $/$ fed $)+0.5$ sheep wool & 8 & 18.19 & 7.00 & 11.19 & 1.39 & 0.30 & 0.4170 \\
\hline 1 ton/fed sheep wool & & 16.31 & 6.23 & 10.08 & 1.45 & 0.25 & 0.3625 \\
\hline $0 . .5$ ton/ fed sheep wool & & 16.25 & 6.11 & 10.14 & 1.49 & 0.25 & 0.3725 \\
\hline control & & 15.01 & 5.19 & 9.82 & 1.51 & 0.24 & 0.3624 \\
\hline Sheep dung ( 10 ton / fed) & & 21.09 & 7.14 & 13.95 & 1.4 & 0.31 & 0.4340 \\
\hline Sheep dung 5 ton / fed & & 18.62 & 6.93 & 11.69 & 1.42 & 0.30 & 0.4260 \\
\hline Sheep dung ( 5 ton $/$ fed $)+1$ ton/fed sheep wool & & 17.96 & 7.08 & 10.88 & 1.37 & 0.30 & 0.4110 \\
\hline Sheep dung $(5$ ton $/$ fed $)+0.5$ sheep wool & $n$ & 17.33 & 6.71 & 10.62 & 1.39 & 0.30 & 0.4170 \\
\hline 1 ton sheep wool & & 15.93 & 5.94 & 9.99 & 1.45 & 0.25 & 0.3625 \\
\hline $0 . .5$ sheep wool & & 15.34 & 5.61 & 9.73 & 1.49 & 0.25 & 0.3725 \\
\hline control & & 15.2 & 5.48 & 9.72 & 1.51 & 0.24 & 0.3624 \\
\hline
\end{tabular}


In July month, 0-5 $\mathrm{cm}$ soil depth, the results showed the increase of Heat Index (cumulative heat content), of 10 ton/fed and 5 ton/fed sheep dung amendments under (100 and $75 \%$ water applied) compare to control was $13.32,10.49 \%, 13.78$ and $12.03 \%$ respectively. However, the increase of Heat Index (cumulative heat content) of 1 ton /fed and 0.5 ton/ fed sheep wool under (100\&75\% water applied) was $<1 \%$.

In $5-10 \mathrm{~cm}$ soil depth, the results showed the increase of Heat Index 14.63, 12.18, 10.07 and 11.68\% for organic amendments, 1.18 and $1.55 \%$ of 1 ton /fed and $0.5 \mathrm{Ton} /$ fed sheep wool respectively. The increase of Heat Index was slightly in $10-15 \mathrm{~cm}$ soil depth. The same trend in August and September months.

\section{The statistical analysis:}

The statistical analysis of variance of two Way Completely Randomized design ANOVA of depth 0-5 and 5-10 cm soil depths, in July, August and September months. The obtain data in table (7) reveal that, the aforementioned trends, whereas the significant and LSD values indicated the dependency of sheep dung, sheep wool and combination sheep dung with sheep wool on Heat Index resulted in highly significant effect and so, $100 \& 75 \%$ water applied. While, there was no significant of sheep wool treatment. Also, there was no significance at $10-15 \mathrm{~cm}$ soil depth for all soil amendments and water applied in July and August months. However, in soil depth $(10-15 \mathrm{~cm})$, total heat content was significantly different between treatments in September, this emphasized that this result obtained as a result of increasing effect of treatments on the depth of the roots and the increase of roots' movement to the bottom, which leads to significant increment in soil heat content in the depth $10-15 \mathrm{~cm}$ at the end of the experiment, because the values of soil heat and water contents were related to roots length and increased with time relatively compared to the values content of soil heat and water of sheep wool treatments and control. The increase in soil water content progressively increased with soil depth at the end of the experiment.

\section{Effect of soil amendments on physical and chemical properties:}

\section{Soil water characteristics:}

Data in Table (6) showed that the amount of available water increased with increasing soil amendments. Under $100 \%$ available water applied, this increase was $45.32,20.88$ and $14.36 \%$ of $10 \mathrm{Ton} / \mathrm{fed}$ sheep dung, 5 ton / fed sheep dung and mixing (5 ton/fed sheep dung +1 ton/fed sheep wool) relative to the control respectively. It is also evident that the available range of soil moisture slightly increased by using sheep wool alone.

Table 7. Statistical analysis ANOVA of Heat Index by integration under soil amendments treatment and irrigation water applied.

\begin{tabular}{|c|c|c|c|c|c|c|c|c|c|c|c|}
\hline \multirow{2}{*}{\multicolumn{2}{|c|}{$\begin{array}{c}\text { Month } \\
\text { Depth per cm }\end{array}$}} & \multicolumn{3}{|c|}{ July month } & \multicolumn{3}{|c|}{ August month } & \multicolumn{3}{|c|}{ September month } & \multirow{3}{*}{$\begin{array}{l}\mathbf{A . W} \\
* * *\end{array}$} \\
\hline & & \multirow{2}{*}{$\begin{array}{l}\mathbf{0 - 5} \\
* * *\end{array}$} & \multirow{2}{*}{$\begin{array}{l}\text { 5-10 } \\
* * *\end{array}$} & \multirow{2}{*}{$\frac{\mathbf{1 0 - 1 5}}{\mathrm{ns}}$} & \multirow{2}{*}{$\frac{\mathbf{0 - 5}}{* * *}$} & \multirow{2}{*}{$\frac{5-10}{* * *}$} & \multirow{2}{*}{$\begin{array}{c}\text { 10-15 } \\
\mathrm{ns}\end{array}$} & \multirow{2}{*}{$\begin{array}{c}\mathbf{0 - 5} \\
* *\end{array}$} & \multirow{2}{*}{$\begin{array}{c}\mathbf{5 - 1 0} \\
* * *\end{array}$} & \multirow{2}{*}{$\frac{10-15}{* *}$} & \\
\hline & Sign. & & & & & & & & & & \\
\hline 离 & $\mathrm{LSD}_{0.05}$ & 99.2 & 124.3 & 153.8 & 109.1 & 135.4 & 227.9 & 224 & 147.4 & 132 & 0.304 \\
\hline \multirow{2}{*}{$\frac{4}{3}$} & Sign. & $* *$ & $* *$ & ns & $* * *$ & $* * *$ & ns & $*$ & $* *$ & ns & $* *$ \\
\hline & $\mathrm{LSD}_{0.05}$ & 53.0 & 66.4 & 82.2 & 58.3 & 72.4 & 121.8 & 119.7 & 78.8 & 70.5 & 0.163 \\
\hline \multicolumn{12}{|c|}{ Rank Mean of Amendments Addition } \\
\hline 10 ton / fed & ep dung & a & a & $\mathrm{a}$ & $\mathrm{a}$ & a & $\mathrm{a}$ & $\mathrm{a}$ & $\mathrm{a}$ & $\mathrm{a}$ & $\mathrm{a}$ \\
\hline 5ton / fed S & dung & $\mathrm{a}$ & $a b$ & $\mathrm{a}$ & $\mathrm{a}$ & $\mathrm{b}$ & $\mathrm{a}$ & $\mathrm{a}$ & $\mathrm{a}$ & $a b$ & $\mathrm{~b}$ \\
\hline $\begin{array}{l}\text { Sheep dung } \\
\text { Sheep wool }\end{array}$ & $\begin{array}{l}\text { on) }+ \\
\text { n) /fed }\end{array}$ & $\mathrm{b}$ & $\mathrm{c}$ & $\mathrm{a}$ & $\mathrm{b}$ & $\mathrm{cd}$ & $\mathrm{a}$ & $\mathrm{bc}$ & $\mathrm{bc}$ & $\mathrm{bc}$ & $\mathrm{c}$ \\
\hline $\begin{array}{l}\text { Sheep dung } \\
\text { Sheep wool }\end{array}$ & $\begin{array}{l}\text { on })+ \\
\text { ton) } / \text { fed }\end{array}$ & $\mathrm{b}$ & $\mathrm{bc}$ & $\mathrm{a}$ & $\mathrm{b}$ & $\mathrm{bc}$ & $\mathrm{a}$ & $a b$ & $\mathrm{~b}$ & $\mathrm{~cd}$ & $\mathrm{c}$ \\
\hline 1ton/fed Sh & wool & $\mathrm{c}$ & d & $\mathrm{a}$ & $\mathrm{c}$ & de & $\mathrm{a}$ & $\mathrm{c}$ & d & $\mathrm{cd}$ & $\mathrm{d}$ \\
\hline 0.5 ton/fed & p wool & $\mathrm{c}$ & d & $\mathrm{a}$ & $\mathrm{c}$ & $\mathrm{e}$ & $\mathrm{a}$ & $\mathrm{c}$ & $\mathrm{cd}$ & d & d \\
\hline Control & & $\mathrm{c}$ & $\mathrm{d}$ & $\mathrm{a}$ & $\mathrm{c}$ & $\mathrm{e}$ & $\mathrm{a}$ & $\mathrm{c}$ & $\mathrm{cd}$ & $\mathrm{d}$ & $\mathrm{d}$ \\
\hline \multicolumn{12}{|c|}{ Rank Mean of irrigation water applied } \\
\hline $100 \%$ & & a & a & a & a & a & a & a & a & a & a \\
\hline $75 \%$ & & $\mathrm{~b}$ & $\mathrm{~b}$ & a & $\mathrm{b}$ & $\mathrm{b}$ & a & $\mathrm{b}$ & $\mathrm{b}$ & a & $\mathrm{b}$ \\
\hline
\end{tabular}


In addition, the values of available water under $100 \%$ water applied was slightly increasing relatively to the values of available water under $75 \%$ water applied of all amendments). Data in table (7) show the effect soil amendments significantly increased the soil available water values relative to the soil control. The highest increasing in the available values was in the soil treated with different soil amendments, and it could be arranged these increment as follows: 10 ton/fed sheep dung $>5$ ton/fed sheep dung $>$ mixing $(5$ ton/fed sheep dung +1 ton/fed sheep wool) $>$ mixing ( 5 ton/fed sheep dung + 0.5 ton/fed sheep wool).

\section{CONCLUSIONS}

Considerable variation of heat content along with water content. the increase in heat content with increasing rate of water applied in soil, which results in the formation of a pronounced peak and a highly in the heat content curve of $100 \%$ water applied but, it was low of $75 \%$ water applied.

The lower total heat content of the upper layers treated with sheep wool and soil control (non treated) relative to the sheep dung could be explained on basis of the sheep wool is insulator for heat, its low of heat capacity and their keep lower of moisture content.

The greater effect of 10 ton/ fed sheep dung on increasing the total heat content in soil of the upper layer $0-5$ and $5-10 \mathrm{~cm}$ could be attributed to its black colour of sheep dung and keep the higher Soil moisture content.

The higher moisture content lowers soil temperature through its effect on evaporation process, which has a cooling effect. In addition, the temperature of the lower layer was always less than the upper one. The difference in temperature between the treated soil and the control was small at $10-15 \mathrm{~cm}$ soil depth. The difference in heat index between the first depth $0-5 \mathrm{~cm}$ and the second one $5-10 \mathrm{~cm}$, was small in the case of 5 ton/fed organic.

In soil depth $10-15 \mathrm{~cm}$, heat index was significant differences between treatments. in September, this emphasized that this result obtained as a result of increasing effect of treatments on the depth of the roots and the increase of roots' movement to the bottom, which leads to significant increment in heat content in the depth $10-15 \mathrm{~cm}$ at the end of the experiment.

\section{REFERENCE}

Abu-Hamdeh Nidal H. 2014. Specific Heat and Volumetric Heat Capacity of Some Saudian Soils as affected by Moisture and Density. Proceedings of the 2014 International Conference on Mechanics, Fluid Mechanics, Heat and Mass Transfer.
Al-Kayssi, A. W. 2009. Impact of elevated CO2 concentrations in the soil solarization efficiency. Applied Soil Ecology, 43: 150 - 158.

Al-Kayssi, A.W., A.A. Al-Karaghouli, A.M. Hasson and S.A. Beker 1991. Influence of soil moisture content on soil temperature and heat storage undergreenhouse conditions J. of Agric Eng Res 45 94) :241-252.

Andrej VONČINA1 and Rok MIHELIČ. 2013. Sheep wool and leather waste as fertilizers in organic production of asparagus. Delo je prispelo 27. septembra 2013, sprejeto 30 .

Bachmann, J., R. Horton, T. Ren, and R.R.Van der Ploge. 2001. Comparison of the thermal properties of four wettable and four water-repellent soils, Soil Sci. Soc. Am.J. 65:1675- 1679.

Buchan, G.D. 2001. Soil temperature regime. In Smith, K.A. and Mullins, E.D. (eds). Soil and environmental analysis: physical methods. Marcel Dekker, New York, 539-594.

Christopher, W.S., H. B. Simon, S.S. Lawrence, D.J. Blake, A. S. Simmons, W.S. James, S. J. Jean and V. S. Gheynst, 2016. The role of organic matter amendment level on soil heating, organic acid accumulation, and development of bacterial communities in solarized soil. Applied Soil Ecology Volume 106, October, Pages 37-46

Gamliel, A., and J.J., Stapleton, 1993. Characterization of antifungal volatile compounds evolved from solarized soil amended with cabbage residues. Phytopathology 83, 899905.

Haskell, E.D., J.D. Flaspohler, R. C. Webster and W.M. Meyer, 2010. Variation in Soil Temperature, Moisture, and Plant Growth with the Addition of Downed Woody Material on Lakeshore Restoration Sites. Society for Ecological Restoration International.10,1526- 1538

Klute, A. 1986. Methods of soil analysis., 2 nd ed. Am. Soc.Agron., Mod. Wisc. USA.

Kohnke-H. 1982. Soil Physics. MC Graw- Hill New Delhi. pp.56-57.

Komariah, K., K. Ito, T. Onishi and M. Senge. 2011. Soil properties affected by combinations of soil solarization and organic amendment. Paddy and Water Environment 9, 357-366.

Lehnert, M., M. Vysoudil and P. Kladivo. 2014. Semistationary measurement as a tool to refine understanding of the soil temperature spatial variability, Int. Agrophys. 29. (4) (2015) 449-457, http://dx.doi.org/10.1515/intag2015-0038, ISSN (Online) 2300-8725.

Ochsnor, T.E., R. Horton and T. Ren 2001. A new perspective on soil thermal properties. Soil Sci. Soc. of Amer. J., 65 (6):1641-1647.

Simmons CW., H. Guo, J.T. Claypool, M.N. Marshall, K.M. Perano, J.J. Stapleton and J.S. Vandergheynst. 2013. Managing compost stability and amendment to soil to enhance soil heating during soil solarization. Waste management. 33(5):1090-1096. 
Taylor, S.A. and R.D. Jackson, 1965. Heat capacity and specific heat. Agronomy, 9, 345-348.

Tyson, E.O., R. Horton and T. Ren, 2001. A new perspective on soil thermal properties. Soil Sci. Soc. Amer. J. 65: 1641-1647.

Usowicz, B. 1992. Statistical-physical model of thermal conductivity in soil, Polish J. Soil Sci.Vol. 1, 27-34.
Yadav, M. R and G. S. Saxena 1973. Effect of compaction and moisture content on specific heat and thermal capacity of soils. Journal Indian Society of Soil Science, 21, 129-132

Wierenga, P. J., D.R. Nielsen and R. M. Hagan 1969. Thermal properties of soil based upon field and laboratory measurements. Soil Sci. Soc. of Amer. Proc., 33, 354360 .

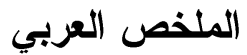

\section{اثر محنات التربة على المحتوى الحرارى والرطوبى للتربة الجيرية}

\author{
هدى عبده ايليا
}

من مخلفات الاغنام (sheep dung) +o+, · طن/ فدان من صوف الأغنام > | طن/فدان صوف اغنام > 0, • طن/ فدان من صوف اغنام > المحتوى الحرارى للتربة غير المعاملة ( كنترول). قد يكون هذا بسبب تأثير المعاملات بمخلفات الاغنام ( sheep dung) على الحاجز المادي بين التربة والهواء الجوي وبالتالي تحسين الاحتفاظ برطوبة التربة والظروف الحرارية لسطح التربة. طبقا للمعادلة : لحساب المساحة الكلية تحت منحنى $(A)=\int_{1}^{9}(x) d x$ المحتوى الحراري (مؤشر الحرارة). أوضحت النتائج كما يلي: في شهر يوليو للعمق •--0 سم ، أن معدلات الزيادة فى مؤشر الحرارة للمعاملات · ل طن /فدان و ه طن /فدان من مخلفات الاغنام (sheep dung) وكميات مياه رى (رى

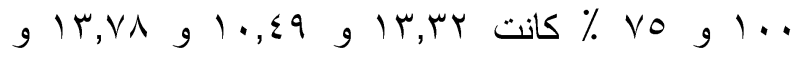
r.,r r ٪ مقارنة القطعة التجريبية غير المعاملة (كنترول) على التوالي. بينما كان مؤشر الحرارة للمعاملات ا طن /فدان و 0, · طن /فدان من صوف الأغنام وعند كميات

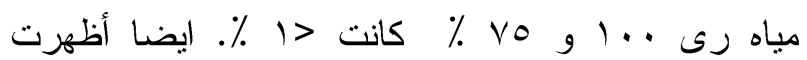
النتائج أن معدلات الزيادة فى مؤشر الحرارة للعمق ه-.

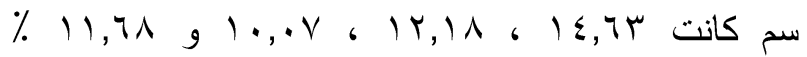
للمعاملات بمخلفات الاغنام (sheep dung). بينما كانت

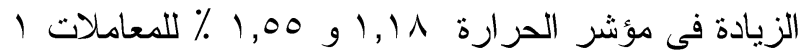

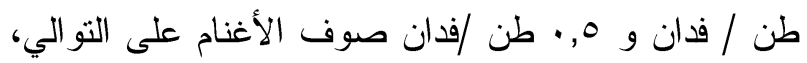
ايضًا ان الزيادة فى (مؤشر الحرارة) قليلة جدا مقارنة

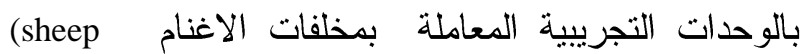

إقيمت تجربة حقلية بمحطة بحوث رأس سدر -التابعة

لمركز بحوث الصحر اء بجنوب سيناء لدراسة تأثير إضافة محسنات التزبة على المحتوى الحرارى و الرطوبى في التربة الجيرية. اجريت التجربة باستخدام ثلاثة معدلات من

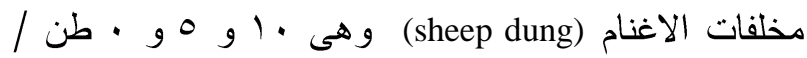
فدان ومعدلين من صوف الأغنام وهى ا وه, · طن / فدان

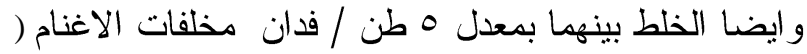

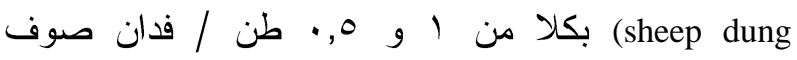

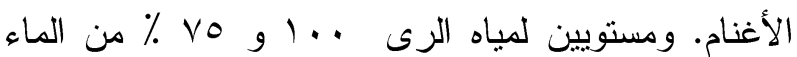
الميسر بإستخدام نظام الرى بالتتقيط. مع زراعة نبات

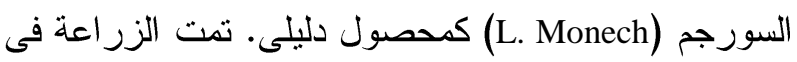
اول يونيو 1 ا.ب م . تم تسجيل درجات الحرارة التربة وتقدير المحتوى الرطوبى لكل ساعة فى نفس الوقت لكل المعاملات تحت الدراسة وذلك بعد كل حشة لنبات السورجم. وذللك ابتداءا من الساعة . . 9 صباحًا وحتى

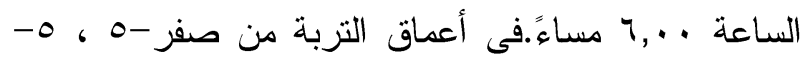

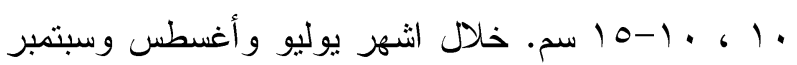
وحساب المحتوى الحرارى بالكالورى لكل عمق تربة . أوضحت النتائج التي ثم الحصول عليها:- أن المحتوى بعى لربه الحرارى بالتزبة (كالورى لكل عمق) للمعاملة ـ طن /فدان من مخلفات الاغنام (sheep dung) > م طن/فدان من مخلفات الاغنام (sheep dung) > خليط كلا من ه طن/ فدان من مخلفات الاغنام (sheep dung) + (طن / فدان من صوف الأغنام > المحتوى الحراى للمعاملة ه طن/ فدان 


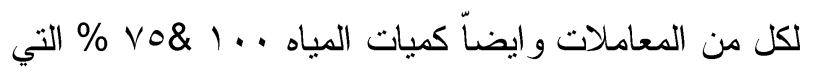
استخدمت فى التجربة لشهري يوليو وأغسطس ، ولكن توجد اختلافات معنوية للمعاملات على مؤشر الحرارة لثهر سبتمبر . هذه النتيجة تؤكد على انه نتيجة لزيادة تأثير

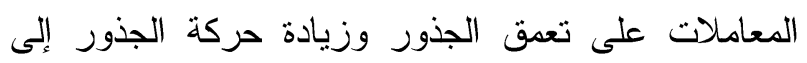
إسفل فى التربة ، مما يؤدي إلى زيادة كبيرة في مؤشر الحرارة في عمق · 1-0 سم عند نهاية التجربة. dung) مؤشر الحرارة في شهرى أغسطس وسبتمبر فى نفس إتجاه النتائج لنهر يوليو ولكن مؤشر الحرارة لثهر أغسطس كان أعلى من مؤشر الحرارة لشهري يوليو وسبتمبر وهذا يرجع إلى ارتفاع درجات حرارة الجو خلال شهر أغسطس. اوضحت النتائج أن هناك نأثير عالى المعنوية بين المعاملات و ايضا هنالك تأثير معنوى بين كميات مياه الرى هئ

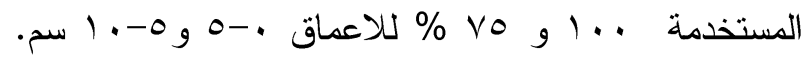
بينما كان هناك تأثير غير معنوى فى العمق · 1-10 سم 